\title{
Ketetapan Tentang Sabat Bagi Umat Israel dalam 10 Hukum Tuhan dan Relevansinya Bagi Orang Percaya Masa Kini
}

\author{
Kristiana Fitriani \\ Sekolah Tinggi Teologi Injili Indoneia (STTII), Palu \\ kristiana.anik@gmail.com
}

\begin{abstract}
Research on the relevance of the Sabbath provisions written in the 10 Laws with the current practice of God's people is intended to find answers whether God's commands are still relevant to God's people today. To the people of Israel the Lord declared His resolve to remember and keep the Sabbath. History also records that the practice of the Sabbath became a very important practice in the lives of the people of Israel. Even that practice was still carried out in the time of Jesus Christ. Until now, there are also churches that practice the Sabbath and make the Sabbath or Saturday a day dedicated to worship. This study uses a qualitative interpretive method, because the research data is more concerned with the interpretation of data found in the field. The results showed that the Sabbath for the people of Israel was a decree from God, which was carried out very thoroughly throughout Israel's history. For God's people today, the provisions regarding the Sabbath remain relevant as provisions aimed at the goodness of God's people. God's people still need the Sabbath to fulfill their spiritual needs, that is, their relationship with God, their physical and mental needs, namely resting from work.
\end{abstract}

Keywords: Sabbath; holy; Jewish; worship.

\begin{abstract}
Abstrak
Penelitian tentang relevansi antara ketetapan Sabat yang dituliskan dalam 10 Hukum dengan praktek hidup umat Tuhan pada masa kini dimaksudkan untuk mencari jawaban apakah perintah Tuhan tersebut masih tetap relevan bagi umat Tuhan masa kini. Kepada bangsa Israel Tuhan menyatakan ketetapan-Nya untuk mengingat dan menguduskan hari Sabat. Sejarah juga mencatat bahwa praktek Sabat menjadi praktek yang sangat penting dalam kehidupan masyarakat Israel. Bahkan praktek tersebut masih dilaksanakan pada zaman Yesus Kristus. Sampai saat ini, ada juga gereja yang melakukan praktek Sabat dan menjadikan hari Sabat atau Sabtu sebagai hari yang dikuduskan untuk beribadah. Penelitian ini menggunakan metode interpretif kualitatif, karena data hasil penelitian lebih berkenaan dengan interpretasi terhadap data yang ditemukan di lapangan. Hasil penelitian menunjukkan bahwa Sabat bagi umat Israel merupakan ketetapan dari Tuhan, yang dilakukan dengan sangat teliti di sepanjang sejarah Israel. Bagi umat Tuhan saat ini, ketetapan tentang Sabat tetap relevan sebagai ketetapan yang bertujuan bagi kebaikan umat Tuhan. Umat Tuhan tetap memerlukan Sabat untuk memenuhi kebutuhan rohani yaitu relasi dengan Tuhan, kebutuhan jiwa dan fisik yaitu beristirahat dari pekerjaan.
\end{abstract}

Kata Kunci: Sabat; kudus; Yahudi; ibadah. 


\section{PENDAHULUAN}

Istilah Sabat mengingatkan perihal berhenti dari pekerjaan atau aktivitas sejenak untuk beristirahat, istirahat, ${ }^{1}$ atau hari yang menjadi waktu bagi gereja Advent beribadah di hari Sabtu, bahkan ada dalam salah satu hukum dalam 10 hukum yang terdapat dalam Keluaran pasal 20. Meskipun sebenarnya pengertian Sabat lebih luas dari semua hal tersebut.

$$
\text { Pembicaraan tentang Sabat }
$$
merupakan topik yang sangat menarik, karena perintah untuk mengingat dan menguduskan hari Sabat yang terdapat dalam 10 Hukum atau Dekalog yang tertulis dalam Keluaran 20, yang merupakan perintah yang berbeda dengan perintah yang lain. Perintah pertama sampai ketiga dilanjutkan dengan perintah keenam sampai kesepuluh merupakan perintah yang sangat lazim dan bersifat universal, artinya masih selalu relevan di sepanjang zaman. Ketetapan atau hukum Tuhan tersebut dapat diterima dan dilakukan bahkan memiliki nilai-nilai moral yang umum dan universal bagi

\footnotetext{
${ }^{1}$ A. Woodruff dan S. Augustin, "Sabbath Day Home Automation", Dalam "Proceedings of SIGCHI Conference of Human Factors in Computing System" (New York: Assosiation for Computing Machinery, 2007), 2.

2 Timotius Fu, "Perhentian Hari Sabat: Makna Dan Aplikasinya Bagi Orang Kristen Dalam Jurnal Veritas," vol. 2 (Malang:
}

semua orang di sepanjang zaman. Berbeda dengan ketetapan atau hukum tentang Sabat, karena menetapkan hari secara spesifik untuk diingat dan dikuduskan hari Sabat yang di maksudkan adalah hari ke tujuh yaitu hari Sabtu dalam kalender yang dipakai secara luas di dunia pada saat ini. Sementara gereja pada umumnya menjadikan hari pertama atau hari Minggu sebagai hari yang dikhususkan untuk beribadah secara kolektif atau bersama.

Tema tentang Sabat memiliki muatan teologis yang kental sehingga dari tema ini muncul pengajaran yang sangat beragam, bahkan cenderung saling bertolak belakang. ${ }^{2}$ Di kelompok yang satu terdapat kelompok orang Kristen yang mengabaikannya karena menganggap hari Sabat sama sekali tidak ada relevansinya dengan kekristenan saat ini. $^{3}$ Di kubu yang berbeda terdapat kelompok orang yang menerapkan pendekatan literal terhadap tema ini sehingga mengelompokkan orang-orang yang gagal menjalankan perintah tentang Sabat ke dalam kelompok orang yang akan menerima hukuman. ${ }^{4}$ Sedangkan di

\footnotetext{
SAAT, 2010), 2.

${ }^{3}$ Richard Gaffin, Calvin and Sabbath: The Controversy of Applying the Fourth Commandent (Ross-shire: Mentor, 1998).

${ }^{4}$ Herald, ed., "Seventh-Day

Adventist Believe: A Biblical Exposition of 27 Fundamental Doctrines," in Ministerial Association General Conference of Seventh-
} 
antara kelompok yang berseberangan tersebut terdapat kelompok orang Kristen yang menerapkan perintah itu secara tersirat. ${ }^{5}$ Tentu saja perbedaan pengertian dan penerapan tersebut bermuara pada penafsiran makna tentang hari Sabat dalam Alkitab.

Apakah praktek Sabat masih relevan bagi umat Tuhan pada masa kini? Apakah ada kaitan antara perintah Sabat dengan kehidupan manusia yang di dalamnya perlu untuk bekerja dan beristirahat? Apa signifikansi Sabat dengan kegiatan ibadah bersama yang dilakukan umat Tuhan saat ini secara rutin dan terorganisir? Apa makna perintah keempat dalam 10 Hukum tersebut bagi orang percaya saat ini? Dan apa relevansi ketetapan tentang Sabat bagi umat Tuhan pada saat ini? Pertanyaan-pertanyaan tersebut yang akan dibahas dalam artikel ini.

Bukan hanya pengertian istirahat yang muncul dalam pemikiran banyak orang ketika mendengar kata sabat, tetapi juga kudus. ${ }^{6}$ Sabat hampir selalu dikaitkan dengan hal menguduskan atau kudus. Berkali-kali dalam pelayanan-Nya, Yesus melakukan penyembuhan di hari Sabat yang menyebabkan orang Yahudi

Day Adventist (Hagerstown, 1988), 263.

${ }^{5}$ A.G Shead, "Sabbath," New Dictionary of Biblical Theology (Inter Varsity, 2010). menuduh Yesus tidak menguduskan hari Sabat. Perintah TUHAN berkenaan dengan Sabat juga mengisyaratkan masalah kekudusan. Dalam Keluaran 20:8 dikatakan "Ingatlah dan kuduskanlah hari Sabat.”

Permasalahan yang muncul bagi umat Tuhan saat ini adalah, apakah ketetapan Sabat yang diberikan dalam 10 Hukum Tuhan, yang masih dibacakan dalam liturgi ibadah Minggu di beberapa gereja masih berlaku bagi orang Kristen masa kini? Dalam hal apa perintah atau ketetapan tersebut tetap perlu dilakukan? Dan apakah ada keterkaitan antara ketetapan Sabat tersebut dengan ibadah bersama yang dilakukan orang Kristen saat ini pada hari Minggu?

Dari sejumlah permasalahan yang muncul, maka penulis akan membahas relevansi ketetapan Sabat dalam Keluaran 20:8-11 tersebut dalam kehidupan orang Kristen pada masa kini.

\section{METODE PENELITIAN}

Metode penelitian yang digunakan adalah jenis penelitian interpretatif kualitatif, karena data hasil penelitian lebih berkenaan dengan interpretasi

\footnotetext{
${ }^{6}$ Erik C. Carter, "The Practice and Experience of the Sabbath among Seventh-Day Adventist Pastors," Pastoral Psychology (2013).
} 
terhadap data yang ditemukan di lapangan. ${ }^{7}$ Penelitian kualitatif adalah penelitian yang yang bersifat deskriptif dan cenderung menggunakan analisis. Penelitian dalam artikel ini dilakukan dengan mencari data-data berkenaan dengan prkatek Sabat dalam kehidupan bangsa Israel dalam sejarah, secara khusus dalam Kitab Keluaran dan Imamat. Selanjutnya melakukan interpretasi tentang relevansi praktek Sabat dalam Perjanjian Lama dan kehidupan umat Tuhan hari ini.

\section{HASIL DAN PEMBAHASAN}

Dalam Pentateukh, istilah Sabat dinyatakan dalam kitab Keluaran dan Kitab Imamat. Namun konsep tentang Sabat nampaknya mulai dari Kitab Kejadian, saat Allah berhenti dari pekerjaan penciptaan. Berkenaan dengan hal ini, John F. Craghan mengatakan "Yahweh menyucikan hari Sabat dan beristirahat (Kejadian 2:2-3) setelah melaksanakan penciptaan."8 Hywel R. Jones menambahkan dengan mengatakan bahwa perintah menguduskan hari Sabat bukanlah perintah yang baru. Dia menjelaskan demikian:

\footnotetext{
${ }^{7}$ Sugiyono, Metode Penelitian Kuantitatif Kualitatif Dan R\&D (Bandung: Alfabeta, 2012).

${ }^{8}$ John F.Craghan, Tafsir Alkitab Perjanjian Lama (Yogyakarta: Kanisius,
}

Ingatlah; ini bukan perintah baru. Ini berasal dari Kejadian 2:1-3. Ini mungkin telah dilupakan oleh orang Israel sewaktu mereka di Mesir dan hal itu tidak disebutkan dalam zaman para leluhur. Ini akan dipelihara untuk selamalamanya. Kerja berat 6 hari memberi hak kepada seseorang atas istirahat satu hari, tetapi hari itu adalah peringatan kepada karya penciptaan oleh Allah untuk keberuntungan manusia dan dengan demikian memberi kesempatan yang sangat cocok bagi pemujaan itu dibuat oleh manusia. ${ }^{9}$

Nyatalah bahwa ketetapan mengenai Sabat adalah ketetapan yang sudah sangat lama dan berlaku turun temurun sebagai ketetapan untuk selamalamanya. Orang Israel memiliki waktuwaktu suci yaitu golongan Sabat dan harihari raya besar. Itulah sebabnya Sabat adalah kudus, dianggap sebagai waktu suci orang Israel.

Dalam kehidupan gereja hari ini, hanya sebagian kecil saja yang masih melaksanakan perayaan dan peringatan Sabat dengan spirit yang sama dengan umat Israel, salah satunya adalah gereja Advent. Kelompok yang masih mempraktekkan Sabat dengan semangat atau spirit yang sama dengan umat Israel

\footnotetext{
2002), 111

${ }^{9}$ Hywel R. Jones, Keluaran Dalam Tafsiran Alkitab Masa Kini (Jakarta: Yayasan Komunikasi Bina Kasih/OMF, 2005), 170.
} 
waktu itu berasumsi bahwa ketetapan Sabat yang tertulis dalam Alkitab berlaku untuk selama-lamanya. Oleh sebab itu, konsisten dengan keyakinan tersebut mereka mempraktekkan seluruh ketentuan Sabat seperti yang ada dalam Alkitab. Di sisi lain, sebagian besar umat Tuhan saat ini berasumsi bahwa tidak semua ketentuan dalam Perjanjian Lama menjadi ketentuan yang harus dilaksanakan persis dengan cara dan spirit yang sama dengan umat Israel pada waktu itu. Mereka beranggapan bahwa ketentuan itu dibuat sebagai gambaran tentang ketentuan yang lebih dalam maknanya dan sudah dipenuhi dalam diri Kristus sebagai kegenapan hukum Taurat, yang memicu suatu perdebatan. Perdebatan tentang hal ini terus berkembang sampai saat ini. Sebagian besar gereja menolak dan tidak melakukan praktek Sabat seperti yang dilakukan gereja Advent.

\section{Pengertian Tentang Sabat}

Kebanyakan orang memahami Sabat sebagai beristirahat atau berhenti dari pekerjaan sebagai pelaksanaan hukum ke-4 dari 10 perintah Allah yang disampaikan melalui Musa dan dituliskan dalam 2 loh batu. Tetapi Sabat memang

\footnotetext{
${ }^{10}$ E.J Young dan F.F Bruce, Sabat Dalam Ensiklopedi Alkitab Masa Kini (Jakarta:
}

lebih luas pengertiannya. Ketentuan tersebut merupakan hukum Allah yang kudus, yang diberikan Allah untuk mengatur kehidupan umat Allah dan memberikan standar kekudusan bagi kehidupan umat Allah.

Sabat (btv Shabat) artinya istirahat atau berhenti bekerja. Dalam ucapan Ashkenaz shabbos, adalah hari istirahat setiap Sabtu dalam Yudaisme. Hari Sabat dirayakan di saat sebelum matahari terbenam pada hari Jumat hingga tibanya malam pada hari Sabtu. Perayaan ini dilakukan oleh banyak orang Yahudi dengan berbagai tingkat keterlibatan dalam Yudaisme.

Dari kata Sabat ini diperoleh istilah Sabbath dalam bahasa Inggris, Sabt dalam bahasa Arab, dan Sabtu dalam bahasa Indonesia. Dari kata ini pula muncul konsep sabatikal, yaitu berhenti bekerja pada Sabat. Orang Yahudi menganggap peringatan Sabat, sebagai hari ketujuh setiap minggu, tidak terputus sejak ditetapkan saat Allah menciptakan alam semesta, dimana manusia dicipta pada hari ke-enam. ${ }^{10}$

Secara etimologi, kata Shabbat dalam bahasa Ibrani berasal dari kata kerja shabbath, dalam bahasa yang sama yang secara harafiah berarti berhenti atau shev

Yayasan Komunikasi Bina Kasih/OMF, 2005), 336. 
yang berarti duduk. Meskipun Sabat hampir secara universal diterjemahkan sebagai istirahat atau suatu masa istirahat, terjemahan yang paling harafiah adalah berhenti, dengan implikasi berhenti dari melakukan pekerjaan. Jadi Sabat adalah hari untuk orang berhenti bekerja, dengan implikasinya beristirahat.

Kata Ibrani untuk mogok berasal dari akar kata Ibrani yang sama dengan Sabat, dan mengandung implikasi yang sama yaitu para buruh yang mogok secara aktif berhenti melakukan pekerjaan dan bukan secara pasif beristirahat. Hal ini dapat menjelaskan pertanyaan teologis yang sering diajukan mengapa Allah perlu beristirahat pada hari yang ke-tujuh dalam penciptaan alam semesta, seperti yang dikisahkan dalam Kejadian pasal 1.

Bila dipahami bahwa Allah berhenti bekerja dan bukan beristirahat dari kerjanya, penggunaan ini lebih konsisten dengan pandangan Alkitab tentang Allah yang Mahakuasa, yang tidak membutuhkan istirahat. Namun demikian, sering diikuti terjemahan yang jauh lebih umum yaitu Sabat sebagai istirahat. Ada kerancuan yang lazim dimana banyak orang percaya bahwa Sabat itu berarti hari ke-tujuh meskipun akar kata untuk tujuh (sheva) hanya merupakan kata yang mirip

${ }^{11}$ F.L. Bakker, Sejarah Kerajaan ucapannya dengan sabat sebagai istirahat.

Sabat berarti berhenti atau perhentian. Dapat juga diartikan istirahat. F.L. Bakker menjelaskan tentang pengertian sabat demikian:

Kata Sabat berarti perhentian; Allah menyucikan hari Sabat, oleh karena pada hari itu Allah berhenti dari pekerjaan-Nya, yakni menjadikan segala apa yang ada. Hari itu adalah hari yang khusus diperuntukkan bagi beribadat kepada Allah. Juga sebelum penerimaan Undang-Undang di Sinai, orang Israel sudah mengenal Sabat (Keluaran 16:27-29). Pada hari Sabat segenap bangsa Israel harus berhenti dari pekerjaannya sehari-hari. Pada hari Sabat mereka tidak boleh menyalakan api (Keluaran 35:3). Siapa yang melanggar peraturan hari Sabat ia akan dihukum mati (Bilangan 15:32-36). Peraturan ini harus juga dituruti dalam waktu panen yang sangat sibuk itu (Keluaran 34:21). Pada hari Sabat harus diadakan pertemuan kudus (Imamat 23:3), kurban persembahan yang diadakan setiap hari haruslah diadakan dua kali lebih banyak untuk hari itu (Bilangan 28:9,10). Pada hari Sabat lah diperbarui roti hadaphadapan (Imamat 24:8). ${ }^{11}$

Melalui penjelasan di atas, jelaslah bahwa Sabat adalah hari perhentian, hari yang dikuduskan untuk beribadah dan hal ini merupakan ketetapan yang berasal dari

Allah, ed. K.Siagian (Jakarta: BPK Gunung Mulia, 2010), 377. 
Tuhan. Sabat bukan sekedar waktu berhenti dari kerja dan saat istirahat bagi umat, tetapi waktu Sabat diisi dengan melakukan ibadah di hadapan Tuhan.

Ada yang memberi penjelasan tentang Sabat yaitu bahwa "pada hari itu orang tidak bekerja, tetapi beristirahat." 12 Seorang lain mengatakan bahwa :

Hari Sabat itu secara khusus dikuduskan untuk menjadi sumber berkat juga, dengan memanggil pemegang gambar raja untuk mengikuti jejak penciptanya. Hari Sabat itu memanggil manusia untuk terus menerus mempersembahkan kembali jabatan raja yang melayani itu kepada kemuliaan Raja Penciptanya. ${ }^{13}$

Selain hari Sabat, rupanya ada juga istilah tahun Sabat. Yang dimaksudkan dengan tahun Sabat adalah keadaan dimana selama satu tahun yaitu tahun ke7 tanah tidak boleh dikerjakan dan ditanami, tanah pun harus beristirahat (Keluaran 23:10-11; Imamat 25:1-7). Hal inipun merupakan ketetapan dan perintah Allah. Bahkan lebih lanjut dijelaskan bahwa Allah menjanjikan akan memberikan hasil bumi tiga kali lipat dalam tahun ke-6.

Hari Sabat maupun tahun Sabat merupakan waktu yang khusus dalam

\footnotetext{
12 Robert M. Paterson, Kitab Keluaran (Jakarta: BPK Gunung Mulia, 2009), 263.

${ }^{13}$ Meredith G. Kline, Kitab Keluaran Dalam Tafsiran Alkitab Masa Kini, ed. Harun
}

penanggalan umat Israel. Umat Israel memiliki waktu-waktu suci yang dibagi menjadi dua, yaitu golongan Sabat yang meliputi hari Sabat, tahun Sabat dan tahun Yobel. Golongan kedua yaitu hari-hari raya besar yang terdiri dari Paskah, Pentakosta, hari Raya Pondok Daun dan hari Pendamaian Besar. ${ }^{14}$

Dengan demikian nyatalah bahwa Sabat adalah perhentian. Baik hari Sabat maupun tahun Sabat, yang ditekankan adalah masalah perhentian. Waktu perhentian itu dikhususkan untuk memberi penyembahan kepada Tuhan. Hal ini merupakan ketetapan yang berasal dari Tuhan yang berlaku untuk selamalamanya.

\section{Sejarah Sabat dalam Kehidupan Umat Israel}

$$
\text { Perayaan Sabat disebutkan }
$$
beberapa kali dalam Torah, terutama sebagai perintah ke-empat dari 10 perintah Allah (Keluaran 20:8-11; Ulangan 5:1215). Contoh-contoh lainnya adalah Keluaran 31:12-17; 35:2-3; Imamat 19:30; dan Bilangan 28:9-10.

Dalam sejarah bangsa-bangsa yang dinyatakan dalam Alkitab, umat Israel

Hadiwijono (Jakarta: Lembaga Komunikasi Bina Kasih/OMF, 2000), 82.

${ }^{14}$ Ibid., 273. 
adalah umat pilihan Allah. Ada beberapa perjanjian yang ada antara Allah dengan umat pilihan-Nya tersebut. Sabat merupakan salah satu kovenan antara Yahweh dan Israel, suatu hubungan khusus Israel dengan Allah. Kepada umatNya, Allah menetapkan sejumlah ketetapan dan ketentuan peribadatan. Segala hal berkenaan dengan peraturan ibadah keagamaan ditetapkan oleh Tuhan. Perintah Sabat mendahului kalender keagamaan atau penetapan hari-hari raya lainnya (Imamat 23:1-3).

Meredith G. Kline menyatakan bahwa sulit untuk menentukan asal usul Sabat. Dia mengatakan "asal usulnya tidak diketahui dan menurut teori, orang Babel, Asyur serta orang Keni merayakan hari demikian sebelum zaman Musa." ${ }^{15}$

Ketetapan tentang Sabat dinyatakan dalam dekalog yang diberikan Allah melalui Musa di Sinai. Namun konsep tentang Sabat sudah ada jauh sebelumnya, sejak masa penciptaan dimana Allah berhenti dari pekerjaan penciptaan dan berhenti di hari ke-7 dan menguduskan hari tersebut. John $F$. Craghan menyatakan "tardisi dahulu menghubungkan pelaksanaan Sabat dengan manna (Keluaran 16:23-30),

${ }^{15}$ Meredith G. Kline, Kitab Keluaran Dalam Tafsiran Alkitab Masa Kini (Jakarta: Yayasan Bina Kasih/OMF, 2000), 82. ${ }^{16}$ John F.Craghan, Tafsir Alkitab sekarang ia mengembangkan makna institusi tersebut kepada Israel."16

Setelah peraturan dan ketetapan Sabat diberikan kepada umat Israel, maka umat Israel dengan setia melakukan ketetapan tersebut. Tidak perlu disangsikan, umat Israel pasti melakukan ketetapan tersebut dengan teliti, tekun dan hormat kepada Allah. Meskipun dalam perkembangannya, orang Farisi pada akhirnya menambahkan berbagai peraturan sendiri dalam peraturan tersebut, sehingga Sabat dalam Perjanjian Baru menjadi kabur dan ada kesan bahwa Sabat itu merupakan suatu legalitas saja. ${ }^{17}$

\section{Peraturan-Peraturan Sabat}

Sebagaimana telah dikemukakan di atas, peraturan dan ketetapan Sabat adalah peraturan atau ketetapan yang diberikan oleh Tuhan sendiri kepada umat pilihan-Nya. Dengan tegas Allah memberi perintah supaya umat-Nya menguduskan Sabat.

Ingatlah dan kuduskanlah hari Sabat, enam hari lamanya engkau bekerja dan melakukan segala pekerjaanmu, tetapi hari ketujuh adalah hari Sabat TUHAN, Allahmu; maka janganlah engkau melakukan

Perjanjian Lama (Yogyakarta: Kanisius, 2002) 111. Allah (Jakarta: BPK Gunung Mulia, 2010), 377. 
Ketetapan Tentang Sabat Bagi Umat Israel Dalam 10 Hukum Tuhan Dan Relevansinya Bagi Orang Percaya Masa Kini $\mid \mathbf{1 7 3}$

suatu pekerjaan, engkau atau anakmu laki-laki, atau anakmu perempuan, atau hambamu lakilaki, atau hambamu perempuan, atau hewanmu, atau orang asing yang di tempat kediamanmu. Sebab enam hari lamanya TUHAN menjadikan langit dan bumi, laut dan segala isinya, dan Ia berhenti pada hari ketujuh; itulah sebabnya TUHAN memberkati hari Sabat dan menguduskannya. ${ }^{18}$

Dari perintah itu, nyatalah bahwa peraturan Sabat yang utama ialah umat Israel dilarang bekerja atau melakukan sesuatu pada hari Sabat. Itulah cara menguduskan hari Sabat.

Umat Israel merayakan Sabat dengan menyajikan makanan yang berlimpah, sebanyak tiga kali setelah kebaktian di sinagoga selesai pada Jumat malam, Sabtu tengah hari, dan Sabtu sore sebelum Sabat berakhir. Lebih banyak orang Yahudi yang berusaha menghadiri kebaktian di sinagoga pada hari Sabat dan mungkin tidak hadir pada hari-hari lainnya.

Selain hari raya Yom Kippur (hari Raya Pendamaian) hari-hari puasa umum ditunda atau dimajukan sehari bila jatuhnya bersamaan pada hari Sabat, dan orang berduka menjalani shivah, dari luarnya berusaha tampil biasa saja selama hari Sabat. Mereka bahkan dilarang untuk menampakkan tanda-tanda duka di muka umum.

Hukum Yahudi melarang penganutnya melakukan segala bentuk melachah (kerja) pada hari Sabat. Melachah tidak sama artinya dengan definisi kerja dalam bahasa lain. Artinya pun tidak sama dengan definisi istilah sebagaimana yang dipergunakan dalam fisika. Kata ini mengacu pada 39 katergori aktivitas yang dilarang oleh Talmud untuk dilakukan pada hari Sabat. Ke-39 kategori ini disimpulkan secara eksegetis berdasarkan perbandingan ayat-ayat Alkitab yang sepadan dari jenis-jenis pekerjaan yang perlu untuk membangun kemah suci.

Banyak ahli agama yang telah menunjukkan bahwa semua kegiatan ini mempunyai kesamaan dengan semua aktivitas bersifat kreatif atau kegiatan yang mengandung kontrol atau kuasa terhadap lingkungan seseorang, ke-39 kegiatan yang dilarang berdasarkan traktat Sabat Misnah 7:2. Ke-39 kegiatan tersebut adalah : menabur, membajak, menuai, mengikat berkas gandum, membuang sampah, menampi, memilih, mengasah, memilah, membuat adonan, membuat roti, menggunting wol, mencuci wol, memukuli wol, mewarnai wol, memintal, menenun, membuat dua simpul, menenum

Lembaga Alkitab Indonesia, 2002).

${ }^{18}$ Keluaran 20:8-11, Alkitab (Jakarta: 
2 lembar benang, memisahkan 2 lembar benang, mengikat, melepaskan ikatan, menjahit robekan, merobek, menjerat, memotong hewan, terbang, mewarnai kulit binatang, menyapu untuk mencari barang yang hilang, menandai kulit binatang, memotong kulit hingga menjadi bentuk tertentu, menulis 2 atau lebih huruf, menghapus 2 atau lebih huruf, membangun, meruntuhkan bangunan, mematikan api, menyalakan api, memberi sentuhan terakhir kepada sebuah benda, memindahkan sebuah benda dari tempat pribadi ke tempat umum, atau sejauh 4 hasta dalam batas tempat umum. ${ }^{19}$

Sedangkan kegiatan yang dianjurkan pada hari Sabat adalah: merayakan Sabat bersama keluarga dekat, pergi ke sinagoga untuk berdoa, mengunjungi keluarga dan teman dalam jarak yang dapat dijangkau dengan berjalan kaki, menerima tamu, menyanyikan zemirot, yaitu nyanyiannyanyian khusus untuk makan Sabat yang biasanya dinyanyikan pada saat dan setelah makan, membaca, mempelajari dan mendiskusikan Torah dan tafsirannya, misnah dan Talmud, mempelajari halakha dan madras, berhubungan seksual antara suami istri pada Jumat malam karena menggabungkan prokreasi dengan

\footnotetext{
${ }^{19}$ E.J Young dan F.F Bruce, Sabat Dalam Ensiklopedi Alkitab Masa Kini
}

sukacita Sabat dan keduanya dianggap di perintahkan oleh Torah. Menurut para rabi reform segala sesuatu yang meningkatkan sukacita Sabat sebagai hari yang khusus dan rohani sangat dianjurkan.

\section{Praktek Sabat}

\section{dalam Kehidupan Umat Israel}

Pertanyaan mendasar yang penting untuk direnungkan adalah, untuk apa Tuhan memberi ketetapan tentang Sabat kepada umat-Nya? Jika memperhatikan Keluaran 20:8-11 dapat disimpulkan bahwa penetapan Sabat mengingatkan bahwa TUHAN adalah Sang Pencipta. Sedangkan jika memperhatikan Imamat 23:4-44, nyatalah bahwa penetapan Sabat dimaksudkan agar umat Israel dapat mengakui bahwa TUHAN adalah pemberi nafkah dan pemelihara.

Umat Israel memelihara dan melaksanakan ketetapan Sabat. Bahkan sampai zaman Tuhan Yesus hidup di dunia, nyatalah bahwa mereka dengan setia melaksanakan Sabat.

Dalam kitab Keluaran, hari Sabat adalah suatu tanda kovenan antara Yahweh dan Israel yang menunjukkan hubungan khusus Israel dengan Allah dan 
bersaksi bahwa kekudusan Israel berakar dalam Allah yang kudus, bukan dalam hukum dan upacara (Keluaran 31:12-17; Im.26:2). Meredith G. Kline mengatakan bahwa "Allah memperluas janji masuk ke Sabat Ilahi dengan memeteraikan pola penjadian dari tujuh hari sebagai lingkaran simbolis yang muncul terus menerus pada keberadaan manusia sehari-hari." ${ }^{20}$

Dari pernyataan tersebut dapat ditarik kesimpulan bahwa ketetapan Sabat diberikan bagi umat sebagai gambaran tentang Sabat yang sesungguhnya, yaitu perhentian selamanya bersama Dia (c.f. Ibr.4).

Bagi umat Israel, Sabat berhubungan dengan berkat. Hal ini dinyatakan oleh Meredith demikian "Hari Sabat itu secara khusus dikuduskan untuk menjadi sumber berkat yang tetap bagi manusia sebagai tanda harapannya yang kekal." ${ }^{21}$

Dalam Alkitab dinyatakan bahwa TUHAN berhenti dalam pekerjaan penciptaan pada hari yang ke-tujuh dan menguduskan hari tersebut (Kejadian 2:23). John F. Craghan mengatakan :

Dengan memperhatikan hari Sabat, orang Israel mengakui kehadiran Yahweh di tengahtengah mereka. Dengan demikian,

${ }^{20}$ Meredith G. Kline, Kitab Keluaran Dalam Tafsiran Alkitab Masa Kini, (Jakarta: Yayasan Bina Kasih/OMF, 2000), 82. 21 Ibid. mereka masuk dalam irama penciptaan, merayakan lagi keterikatan mereka dengan Allah Sang Pencipta dan dengan dunia ciptaan-Nya. Bangsa Israel itu dikuduskan dan diserahkan kepada Yahweh sebagaimana Sabat juga dikuduskan dan diserahkan kepada Yahweh. ${ }^{22}$

Pada prinsipnya, Sabat memiliki makna rohani bagi umat Israel. Mengingatkan Israel akan pribadi dan karya Tuhan yang ajaib, juga mengingatkan hubungannya yang sangat spesial di mata Tuhan.

Selain dari sudut pandang rohani, praktek Sabat yang dilakukan umat Israel juga memiliki makna dalam hal sosial dan ekonomi. Dengan mengutip pendapat John H.Yoder dalam The Politics of Jesus, Andrew E.Hill dan John H.Walton mengatakan demikian:

Peraturan-peraturan hari Sabat dan tahun Sabat dimaksudkan untuk membantu perkembangan persamaan hak di bidang sosial dan ekonomi serta menanamkan prinsip-prinsip komunitas perjanjian yang penting dalam masyarakat Ibrani. Ini meliputi pertama, pengucapan syukur atas bantuan dan pemeliharaan pada masa lampau dan iman bahwa Allah akan terus memelihara selama tahun perhentian, kedua, pengampunan dalam

22 John F.Craghan, Tafsir Alkitab Perjanjian Lama (Yogyakarta: Kanisius, 2002), 111-112. 
penghapusan utang-utang, ketiga, menghormati orangorang yang diciptakan menurut gambar Allah dalam pembebasan budak-budak, dan keempat, praktik kedermawanan dan gagasan penatalayanan dalam pembagian kembali negeri perjanjian itu. ${ }^{23}$

Bukan hanya ketetapan hari

Sabat yang berkaitan dengan masalah sosial dan ekonomi, ketetapan tentang tahun Sabat juga berkaitan dengan masalah sosial dan ekonomi. Alkitab menyatakan bahwa setelah enam tahun menabur, mengolah dan menuai, tanah harus dibiarkan tidak ditanami pada tahun yang ke-tujuh (Imamat 25:1-7). Secara praktis, orang miskin dan mereka yang secara ekonomi tidak beruntung, memperoleh manfaat dari tahun Sabat, karena mereka dapat mengambil sisa-sisa hasil dari tanah yang tidak ditanami (Keluaran 23:11).

Hukum dalam kitab Ulangan memperluas program Sabat dalam hal penghapusan hutang, bantuan yang melimpah untuk orang-orang miskin dan pembebasan budak-budak Ibrani (Ulangan 15:2-18).

Terlihat dengan jelas bahwa ketetapan Sabat ternyata bukan hanya berkaitan dengan masalah rohani saja,

\footnotetext{
${ }^{23}$ Andrew E.Hill dan John H.Walton,
}

yang mengingatkan umat Israel tentang kuasa dan karya Allah sekaligus mengingatkan tentang hubungan yang unik dan special antara Allah dan umatNya, tetapi juga berkaitan dengan masalah sosial dan ekonomi.

Dalam Kehidupan Umat Tuhan Saat Ini Pertanyaan selanjutnya yang perlu dijawab adalah apa arti semua itu bagi kehidupan umat Kristen masa kini? Dalam Perjanjian Baru bahkan ada beberapa kisah dimana Tuhan Yesus sendiri tidak melakukan seperti yang dilakukan orang Yahudi berkenaan dengan Sabat. Dan hal itulah yang menyebabkan kebencian banyak orang Yahudi terhadap Yesus. Beberapa kali Yesus melakukan sesuatu yang tidak lazim dilakukan di hari Sabat, misalnya menyembuhkan orang sakit di hari Sabat. Rupanya ada peraturan-peraturan yang ditambahkan olah orang Farisi terhadap peraturan Sabat yang ditentukan oleh Allah sendiri. Itulah sebabnya Yesus melakukan hal yang benar dan mengatakan bahwa Dia adalah Tuhan atas hari Sabat. Berkenaan dengan hal tersebut, Hill dan Weaton mengatakan "pada zaman Yesus, manfaat-manfaat praktis dan kemanusiaan hari Sabat sudah dikaburkan 
bahkan boleh dikatakan hilang oleh legalisme Yudaisme (Matius 12:1-4; Markus 7:1-13). ${ }^{.24}$

Hari ini, kebanyakan atau bahkan hampir semua orang Kristen sudah tidak melakukan praktek Sabat, dengan spirit dan cara yang sama dengan yang dilakukan umat Israel. Apakah hal ini berarti ketetapan Sabat dari Allah kepada umat Israel tidak berguna sama sekali bagi umat Tuhan masa kini?

Hari ini umat Tuhan beribadah di hari Minggu, hari pertama dalam penanggalan Yahudi. Kegiatan ibadah yang dilakukan juga tidak sama dengan praktek Sabat orang Israel. Namun demikian, ada beberapa hal yang dapat menjadi pelajaran penting bagi umat Kristen berkenaan dengan ketetapan Sabat dalam kitab Pentatukh. Pelajaranpelajaran penting tersebut pertama, praktek Sabat yang dilakukan umat Israel dengan teliti, tekun dan setia menjadi contoh bagi umat Tuhan pada masa kini untuk setia juga melakukan segala ketetapan Tuhan bagi generasi ini. Kedua, Sabat mengingatkan bahwa Allah adalah Sang Pencipta dan penguasa atas segala ciptaan-Nya. Umat Tuhan masa kini perlu menyadari hal tersebut. Ketiga, Sabat menyatakan bahwa Israel sangat spesial dan memiliki hubungan yang khusus dan unik dengan Allah, begitu juga umat Tuhan masa kini, sangat spesial dan unik di hadapan Tuhan. Keempat, Sabat mengajar tentang adanya keseimbangan antara bekerja dan berhenti bekerja. Jika Allah memberi teladan dan mengajarkan prinsip keseimbangan, maka sudah seharusnya umat Tuhan juga menjaga hal ini dalam hidup dan pelayanan serta pengabdian kepada Tuhan. Kelima, Sabat umat Israel juga mengajar tentang kepedulian terhadap orang miskin, dalam hal ini adalah tahun Sabat. Orang miskin mendapat sisa-sisa hasil panen atas tanah yang tidak ditanani selama satu tahun. Hal ini seharusnya mendorong orang percaya pada masa kini untuk juga memiliki kepedulian yang sama terhadap sesama. Keenam, salah satu ketentuan Sabat, dalam hal ini tahun Sabat, mengajar umat Israel untuk belajar hidup beriman bahwa Tuhan memberkati dan mencukupkan meskipun selama satu tahun tanah tidak diolah. Umat Tuhan pada masa kini juga perlu untuk terus beriman dan meyakini pemeliharaan Tuhan dalam kehidupan setiap hari.

Perintah Allah terhadap umat Israel adalah supaya umat Israael mengingat dan menguduskan hari Sabat. 
Untuk memahami makna istilah mengingat dan menguduskan hari Sabat, ada baiknya memperhatikan tulisan Robert Paterson demikian:

Ingatlah (zakor) dalam bahasa Ibrani. Implikasi dari mengingat ialah merayakan hari Sabat sebagai kenyataan yang ada sekarang. Dalam U1.5:12, kata kerja yang dipakai berbeda, yaitu syamar yang artinya peganglah atau jagalah. Kuduskanlah yaitu menganggapnya sebagai hari khusus untuk Tuhan. ${ }^{25}$

Sikap peghormatan terhadap hari

Sabat juga penting untuk diikuti. Umat

Tuhan hari ini seharusnya memiliki sikap penghormatan terhadap waktu ibadah, memberi waktu khusus untuk beribadah kepada Tuhan pencipta semesta sekalian alam ini.

\section{KESIMPULAN DAN SARAN}

Sabat merupakan ketetapan atau perintah Tuhan yang tetap relevan bagi umat-Nya. Perintah tersebut bertujuan untuk kebaikan umat Tuhan, yaitu terpenuhinya kebutuhan rohani untuk selalu menjalin relasi khusus dengan Tuhan, kebutuhan jiwa dan fisik yaitu saat untuk beristirahat dari pekerjaan. Umat Tuhan saat ini seharusnya tetap melakukan perintah Sabat dengan spirit yang sama seperti umat Israel tetapi dengan interpretasi yang berbeda terhadap praktek Sabat. Bukan dengan keterikatan pada ketetapan-ketetapan tambahan yang ada saat itu yang justru menjadi hal yang tidak sesuai dengan perintah Tuhan yang sebenarnya. Bukan dengan cara yang kaku dan terkesan legalistik. Kasih terhadap sesama juga perlu mendapat pertimbangan utama. Prinsipnya, umat Tuhan hari ini harus memiliki waktu khusus untuk beribadah dan menghormati waktu khusus tersebut.

\section{DAFTAR PUSTAKA}

Keluaran 20:8-11. Alkitab. Jakarta: Lembaga Alkitab Indonesia, 2002.

A. Woodruff dan S. Augustin. "Sabbath Day Home Automation", Dalam "Proceedings of SIGCHI Conference of Human Factors in Computing System." New York: Assosiation for Computing Machinery, 2007.

A.G Shead. "Sabbath." New Dictionary of Biblical Theology. Inter Varsity, 2010.

Andrew E.Hill dan John H.Walton. Survei Perjanjian Lama. Malang: Gandum Mas, 1996.

Carter, Erik C. "The Practice and Experience of the Sabbath among Seventh-Day Adventist Pastors."

(Jakarta: BPK Gunung Mulia, 2009), 263. 
Pastoral Psychology, 2013.

E.J Young dan F.F Bruce. Sabat Dalam Ensiklopedi Alkitab Masa Kini. Jakarta: Yayasan Komunikasi Bina Kasih/OMF, 2002.

F.L. Bakker. Sejarah Kerajaan Allah. Edited by K.Siagian. Jakarta: BPK Gunung Mulia, 2010.

Gaffin, Richard. Calvin and Sabbath: The Controversy of Applying the Fourth Commandent. Ross-shire: Mentor, 1998.

Herald, ed. "Seventh-Day Adventist Believe: A Biblical Exposition of 27 Fundamental Doctrines." In Ministerial Association General Conference of Seventh-Day Adventist, 263. Hagerstown, 1988.

Hywel R.Jones. Keluaran Dalam Tafsiran Alkitab Masa Kini. Jakarta: Yayasan Komunikasi Bina Kasih/OMF, 2005. John F.Craghan. Tafsir Alkitab Perjanjian Lama. Yogyakarta: Kanisius, 2002. Tafsir Alkitab Perjanjian Lama. Yogyakarta: Kanisius, 2002.

Meredith G. Kline. Kitab Keluaran Dalam Tafsiran Alkitab Masa Kini. Edited by Harun Hadiwijono. Jakarta: Lembaga Komunikasi Bina Kasih/OMF, 2000.

Paterson, Robert M. Kitab Keluaran. Jakarta: BPK Gunung Mulia, 2009.

Sugiyono. Metode Penelitian Kuantitatif Kualitatif Dan R\&D. Bandung: Alfabeta, 2012.

Timotius Fu. "Perhentian Hari Sabat: Makna Dan Aplikasinya Bagi Orang
Kristen Dalam Jurnal Veritas Volume 2." 2:2. Malang: SAAT, 2010 . 
180 | SANCTUM DOMINE: Jurnal Teologi, vol. 19, no. 2 (2020) 